\title{
Stand Transpiration Estimates from Recalibrated Parameters for the Granier Equation in a Chinese Fir (Cunninghamia lanceolata) Plantation in Southern China
}

\author{
Shuai Ouyang ${ }^{1,2}$, Kaiyu Xiao ${ }^{1,2}$, Zhonghui Zhao ${ }^{1,2, *}$, Wenhua Xiang ${ }^{1,2} \mathbb{D}^{\mathbb{D}}$, Chuanhong Xu ${ }^{1}$, \\ Pifeng Lei ${ }^{1,2}$, Xiangwen Deng ${ }^{1,2}$ and Jiangrong $\mathrm{Li}^{3}$ \\ 1 Faculty of Life Science and Technology, Central South University of Forestry and Technology, \\ Changsha 410004, China; yangshuai8613@163.com (S.O.); t123v@163.com (K.X.); \\ xiangwh2005@163.com (W.X.); xuchuanhong1994@163.com (C.X.); pifeng.lei@yahoo.com (P.L.); \\ dxwfree@126.com (X.D.) \\ 2 Huitong National Station for Scientific Observation and Research of Chinese Fir Plantation Ecosystems in \\ Hunan Province, Huitong 438107, China \\ 3 Ecological Research Institute of Xizang Plateau, Tibet Agricultural and Animal Husbandry University, \\ Linzhi 860000, China; ljrong06@126.com \\ * Correspondence: zhaozhznl@163.com; Tel./Fax: +86-731-8562-3483
}

Received: 2 February 2018; Accepted: 22 March 2018; Published: 23 March 2018

\begin{abstract}
Chinese fir (Cunninghamia lanceolata (Lamb.) Hook) is an important native tree species that is widely distributed in subtropical areas of southern China and cultivated for wood extraction. However, information on water use by Chinese fir plantations is still scarce. In this study, we performed species-specific parameter calibrations for the original Granier equation for sap flow density $(S F D)$ estimates. Stand transpiration $\left(E_{\mathrm{s}}\right)$ was related to environmental inputs, such as rainfall, air temperature $\left(\mathrm{T}_{\mathrm{a}}\right)$, vapor pressure deficit $(\mathrm{VPD})$, photosynthetically-active radiation (PAR), air relative humidity (RH), and potential evapotranspiration (PET) in order to examine how environmental factors affect the $E_{\mathrm{S}}$ of Chinese fir plantations. According to our results, Granier's original parameters set underestimated C. lanceolata SFD by up to $54 \%$ compared to our species-specific calibrated parameters set. A strong positive correlation was found between SFD, diameter at breast height (DBH), and tree height among trees populations. The total $E_{\mathrm{S}}$ in 2015 was $522.1 \mathrm{~mm}$, with obvious seasonal dynamics and an average of $1.4 \mathrm{~mm} \cdot \mathrm{day}^{-1}$. Daily and monthly $E_{\mathrm{s}}$ were positively correlated with VPD, PAR, $\mathrm{T}_{\mathrm{a}}$, and PET. A negative relationship between $E_{\mathrm{s}}$ and $\mathrm{RH}$ was detected only at a daily timescale. Our findings indicate that the original Granier equation requires a parameter calibration when it is applied to species-specific thermal dissipation probe (TDP) estimates, and our findings can also provide novel insights on the water use of Chinese fir in major wood production areas in Southern China.
\end{abstract}

Keywords: sap flow density; stand transpiration; water use; Cunninghamia lanceolata

\section{Introduction}

The hydrological budget is one of the most important functions in terrestrial ecosystems and is crucial for both environmental and economic development [1,2]. Transpiration is a key element of the hydrological cycle and a main component driving water balances in forest ecosystems [3-5]. Accurate estimates of the transpiration of forest ecosystems, as well as an examination of its affecting factors, are critical for understanding the effects of forest characteristics on hydrological processes and watershed water resources management $[5,6]$. 
Transpiration in woody plants is often estimated based on sap flow density (SFD) [7]. The thermal dissipation probe (TDP) method is currently the most widely-used method for measuring SFD, which can provide information on water use at an individual tree scale and stand scale in forest ecosystems [8]. Granier [9] derived an empirical equation to calculate SFD based on the measurements of one hardwood species (Quercus pedunculata Ehrh.) and two conifer species (Pinus nigra Arnold and Pseudotsuga menziesii (Mirb.)):

$$
S F D=a \times K^{b}
$$

where SFD has the units of $\mathrm{cm}^{3} \mathrm{~cm}^{-2} \mathrm{~s}^{-1}, a$ and $b$ are empirical parameters with the estimated values of 0.0119 and 1.23 , respectively, and $K$ is a dimensionless quantity related to the temperature difference between a heated probe and a reference (unheated) probe. However, some studies have reported that the original equation could not accurately estimate SFD in all situations, and that specific parameter ( $a$ and $b$ ) calibration was required when it is applied [10-12]. For example, Bush et al. [13] found that the actual species-specific parameters differed by nearly two orders of magnitude when compared with the original equation parameters. Sun et al. [11] reported that a 9-55\% discrepancy in SFD estimates occurred between the actual calibration parameters and the original equation parameters. Therefore, the species-specific parameter values derived from the empirical equation used for TDP could provide accurate estimates of $S F D$, regarding xylem anatomy or stem size.

Investigating the factors governing plant transpiration is important in order to understand the water use of forests in response to climate change. $E_{\mathrm{s}}$ is closely related to meteorological factors, such as air temperature, vapor pressure deficit (VPD), wind speed, relative humidity, and solar radiation (Rs) [14-16]. Soil moisture also influences $E_{\mathrm{s}}$ [17-19]. For instance, Jiao et al. [19] found that the status of soil moisture content at the beginning of the growing season impacted $E_{\mathrm{s}}$ significantly during the growing season. Moreover, some studies have shown that the dominant factors affecting stand transpiration may vary at different timescales [20,21]. At a short timescale (e.g., daily and weekly), both Rs and VPD control the transpiration rate by affecting stomatal conductance, with VPD being the most correlated [22]. At longer timescales (e.g., monthly and seasonally), however, rainfall and other related factors may be expected to exert differing degrees of influence [4]. Understanding the influence of climatic factors on $E_{\mathrm{s}}$ is, therefore, necessary for the evaluation and modeling of the physiological processes related to transpiration in the process-based biogeochemistry model.

Chinese fir (Cunninghamia lanceolata (Lamb.) Hook) is the principal species used for cultivating that has traditionally been managed for timber production due to its fast-growth rate and excellent wood quality [23]. Chinese fir plantations provide a great deal of economic values (e.g., timber production) to farmers at the local and national levels [24]. According to Lei [25], Chinese fir plantations expanded rapidly in the past four decades and their total planted area is now more than 9.21 million hectares, accounting for $35 \%$ of the total plantation area in China [23,24]. Recent studies reported that Chinese fir plantations had positive effects on ecosystem services (e.g., carbon sequestration; soil erosion preservation) $[23,26]$. However, despite their economic importance and ecosystem services, studies of the soil water use of Chinese fir plantations are lacking [27,28]. Hence, water use characteristics of Chinese fir plantations are worthy to be investigated thoroughly using the advanced sap flow measurement technology. In this study, we expect that the original Granier equation $[9,29]$ results in biases of sap flow estimates in Chinese fir plantations. We hypothesize that the accuracy could be improved after the re-calibration of species-specific parameters of the Granier equation for Chinese fir plantations. The present study had three objectives:

(1) to test the need for species-specific parameters for the original Granier's equation in C. lanceolata;

(2) to examine seasonal variations in $E_{\mathrm{s}}$;

(3) to determine how climatic variables affect $E_{\mathrm{s}}$ in a $C$. lanceolata plantation. 


\section{Materials and Methods}

\subsection{Study Site}

This study was conducted at the Huitong National Field Station for Scientific Observation Experiment for Chinese Fir Ecosystem (latitude $26^{\circ} 50^{\prime} \mathrm{N}$, longitude $109^{\circ} 45^{\prime} \mathrm{E}$ ). The study site has an elevation ranging from 280 to $390 \mathrm{~m}$ a.s.l, with a typical humid subtropical monsoon climate. The annual mean air temperature at the site is about $16.8{ }^{\circ} \mathrm{C}$, with a mean monthly minimum temperature of $4.4^{\circ} \mathrm{C}$ in January and a mean monthly maximum temperature of $26.3{ }^{\circ} \mathrm{C}$ in July. The annual rainfall averages $1268 \mathrm{~mm}$, fluctuating between 944 and $1681 \mathrm{~mm}$. The soil type is well-drained clay loam red soil, developed on slate and shale parent rock classified as lliti-Udic Ferrosols, corresponding to Acrisol in the World Reference Base for Soil Resources (Institute of Soil Science, Chinese Academy of Science 2001).

The Chinese fir plantation was 20 years old in 2015 and was the reforestation of a second rotation stand after a clear-cut in 1996. An experimental plot with an area of $25 \mathrm{~m} \times 20 \mathrm{~m}$ was established in the center of the plantation for sap flow measurements. The plot was at a middle slope position, and the slope floor was flat. There were 100 trees in the plot in 2015 when this study was being carried out (Figure 1).

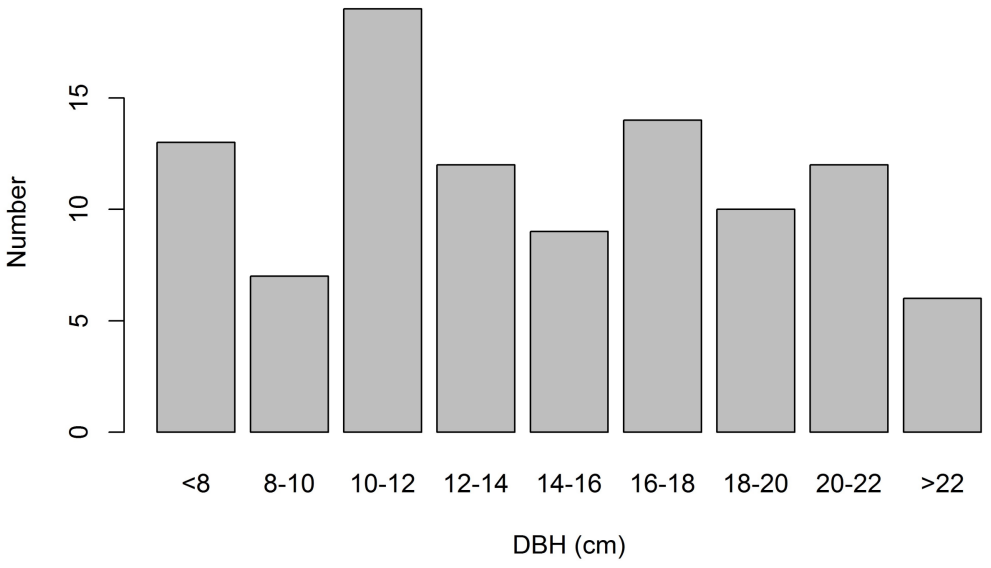

Figure 1. Distribution of the values of the tree diameter at breast height (DBH) in the study plot.

\subsection{Meteorological Variables}

The meteorological variables were measured in an adjacent open area outside the stands. They include air temperature $\left(\mathrm{T}_{\mathrm{a}}\right)\left({ }^{\circ} \mathrm{C}\right)$, rainfall $(\mathrm{mm})$, photosynthetically-active radiation (PAR) (umol $\left.\mathrm{m}^{2} \mathrm{~s}^{-1}\right)$, and air relative humidity $(\mathrm{RH})(\%)$. Air temperature and $\mathrm{RH}$ were measured by a thermohygrograph (HMP50, Vaisala, Helsinki, Finland). Rainfall was measured using a tipping-bucket rain gauge (Davis Rain collector II model 7852, Davis Instruments, Hayward, CA, USA), and PAR was measured using a pyranometer (LI-200, Li-Cor Inc., Lincoln, NE, USA). Measurements were recorded every $30 \mathrm{~s}$ and stored in a 30-min average in a data logger (CR10X, Campbell Scientific, Logan, UT, USA). VPD was calculated using relative humidity and temperature, as described by Campbell and Norman [30]. The daily potential evapotranspiration (PET) was calculated using the Food and Agriculture Organization (FAO) Penman-Monteith equation, described by Allen et al. [31].

\subsection{Sapwood Area Determination}

To avoid damaging the sampled trees used for sap flow measurements, a total of 40 core samples were collected using an increment borer (Haglöf Increment Borer, Långsele, Sweden) from 40 trees near the plot in order to identify the sapwood area, with samples covering a wide range of DBH classes. The yellowish sapwood from Chinese firs has a high moisture content and was easy to distinguish from 
the brown-colored heartwood in order to extract the cores. The sapwood area $\left(A_{\mathrm{S}}\right)$ was determined via the difference between the stem cross-sectional area beneath the bark and the heartwood area. Following Vertessy et al. [32], an allometric equation was used to relate $A_{\mathrm{s}}$ to $D B H$ :

$$
A_{\mathrm{S}}=B_{0} \times D B H^{B_{1}}
$$

where $B_{0}$ and $B_{1}$ are parameters of the equation.

\subsection{Laboratory Experiment for Calibrating the Parameters of the Original Granier Equation}

To test the accuracy of the original calibration equation proposed by Granier $[9,29]$, a calibration system was built using cut stem segments from three Chinese fir trunks, using the gravimetric method described by Steppe et al. [33]. All stem segments were processed according to the procedure followed by Shinohara et al. [34]. Constant heads of water of 10, 20, 30, 40, 60, 80, and $100 \mathrm{~cm}$ were maintained on each cut stem segment for at least half an hour during the experiments.

\subsection{Field Sap Flux Measurements and Scaling up of Sap Flux from Individual Trees to Stand}

The SFD of 18 trees, representing the range of DBH classes in the study plot, were measured using Granier-type sensors [29] (Table 1) in 2015. The sensors were installed only at the north-facing side of 11 trees (tree nos. 1-11) and on two aspects (north and south) of seven trees (tree nos. 12-18) at a height of $1.3 \mathrm{~m}$ in order to quantify the azimuthal impacts in SFD. Each sensor consisted of two stainless steel probes, $10 \mathrm{~mm}$ long and $2 \mathrm{~mm}$ in diameter, inserted approximately $5 \mathrm{~cm}$ apart along the axis of the sapwood. The upper probe was heated by being supplied with a constant power of $0.2 \mathrm{~W}$, while the lower probe remained unheated, and the temperature difference between the two probes was converted to SFD according to the calibrated equation used in this study. Sap flow signals were recorded every $30 \mathrm{~s}$ and averaged over $30 \mathrm{~min}$ in a data logger (CR1000, Campbell Scientific, Logan, UT, USA) with a multiplexer (AM16/32, Campbell Scientific, Logan, UT, USA). To minimize the thermal interference caused by direct sunlight and wind, the sensors were shielded with aluminum foil.

Table 1. Characteristics of the 18 sampled trees, and the number and aspects of sensors (N: North, S: South).

\begin{tabular}{ccccc}
\hline Tree No. & $\begin{array}{c}\text { Measured } \\
\text { Position }\end{array}$ & DBH (cm) & Height $(\mathbf{m})$ & $\begin{array}{c}\text { Sapwood Area } \\
\left.\mathbf{( c m}^{\mathbf{2}}\right)\end{array}$ \\
\hline 1 & $\mathrm{~N}$ & 10.4 & 12.0 & 61.32 \\
2 & $\mathrm{~N}$ & 11.2 & 13.8 & 70.48 \\
3 & $\mathrm{~N}$ & 12.6 & 13.5 & 87.93 \\
4 & $\mathrm{~N}$ & 13.8 & 15.5 & 104.30 \\
5 & $\mathrm{~N}$ & 14.0 & 15.0 & 107.16 \\
6 & $\mathrm{~N}$ & 15.7 & 13.5 & 132.89 \\
7 & $\mathrm{~N}$ & 16.6 & 14.0 & 147.55 \\
8 & $\mathrm{~N}$ & 17.1 & 14.0 & 156.01 \\
9 & $\mathrm{~N}$ & 17.2 & 17.1 & 157.72 \\
10 & $\mathrm{~N}$ & 17.4 & 16.0 & 161.19 \\
11 & $\mathrm{~N}$ & 18.4 & 17.7 & 179.02 \\
12 & $\mathrm{~N}, \mathrm{~S}$ & 18.5 & 19.0 & 180.85 \\
13 & $\mathrm{~N}, \mathrm{~S}$ & 19.1 & 18.8 & 192.02 \\
14 & $\mathrm{~N}, \mathrm{~S}$ & 20.2 & 18.0 & 213.31 \\
15 & $\mathrm{~N}, \mathrm{~S}$ & 20.5 & 18.8 & 219.29 \\
16 & $\mathrm{~N}, \mathrm{~S}$ & 21.9 & 18.4 & 248.26 \\
17 & $\mathrm{~N}, \mathrm{~S}$ & 22.3 & 20.5 & 256.84 \\
18 & $\mathrm{~N}, \mathrm{~S}$ & 23.4 & 20.0 & 281.14 \\
\hline
\end{tabular}

Whole-tree sap flow $(F)$ was calculated as the product of SFD and the sapwood cross-sectional area [29]:

$$
F=S F D \times A_{S}
$$


$E_{\mathrm{s}}$ was calculated from the sap flow measurements of individual trees using the following equation [35]:

$$
E_{\mathrm{s}}=S F D_{\text {mean }} \times \frac{A_{\mathrm{ST}}}{A_{\mathrm{G}}}
$$

where $E_{\mathrm{S}}$ is the stand transpiration, $S F D_{\text {mean }}$ is the mean stand $S F D, A_{\mathrm{ST}}$ is the total cross-sectional sapwood area in the study plot, and $A_{\mathrm{G}}$ is the ground area in the plot. $S F D$ mean was calculated as:

$$
S F D_{\text {mean }}=\frac{\sum_{i}^{n} F_{\mathrm{i}} \times A_{\mathrm{si}}}{A_{\mathrm{ST}}}
$$

where $F_{\mathrm{i}}$ is the average $S F D$ of the $i$ th DBH class and $A_{\mathrm{si}}$ is the total sapwood area of the sample trees of the $i$ th DBH class.

\subsection{Statistical Analysis}

Recalibration curves were produced by fitting a least-squares power function to the pooled data for all measured segments. Pearson's correlation analysis was used to test the significance of correlations between SFD, DBH, and tree height. An exponential threshold model was used [36] to analyze the effects of VPD and PAR on $E_{\mathrm{s}}$ at a daily scale:

$$
E_{\mathrm{S}}=a \times\left(1-e^{-b \times X}\right)
$$

where $a$ and $b$ are fitting parameters, $E_{\mathrm{S}}$ is daily transpiration, and $X$ is the corresponding climate variable. The effects of rainfall, $\mathrm{T}_{\mathrm{a}}, \mathrm{RH}$, and PET on the daily $E_{\mathrm{s}}$ and monthly $E_{\mathrm{s}}$ were investigated by linear regression. All analyses were performed in R 3.00 statistical software (R Development Core Team, 2015) for Microsoft Windows 10 [37].

\section{Results}

\subsection{Climate Variables during the Study Period}

The daily climate variables showed distinctive seasonal variations during the period (Figure 2). A gross rainfall of $1400.0 \mathrm{~mm}$ was recorded at the study site, which occurred mainly from April to September, and exhibited high intra-annual variability. The mean daily air temperature was $16.3^{\circ} \mathrm{C}$, with the minimum of $-0.1{ }^{\circ} \mathrm{C}$ recorded in January and a maximum of $28.9{ }^{\circ} \mathrm{C}$ observed in June (Figure 2). The mean daily PAR was $37.3 \mathrm{~mol} \mathrm{~m}^{-2} \mathrm{day}^{-1}$, and the lowest values were generally observed between January and March, while the highest values were observed between July and August (Figure 2). The mean daily VPD was $4.0 \mathrm{hPa}$, with high values observed in July and low values observed in December (Figure 2). 

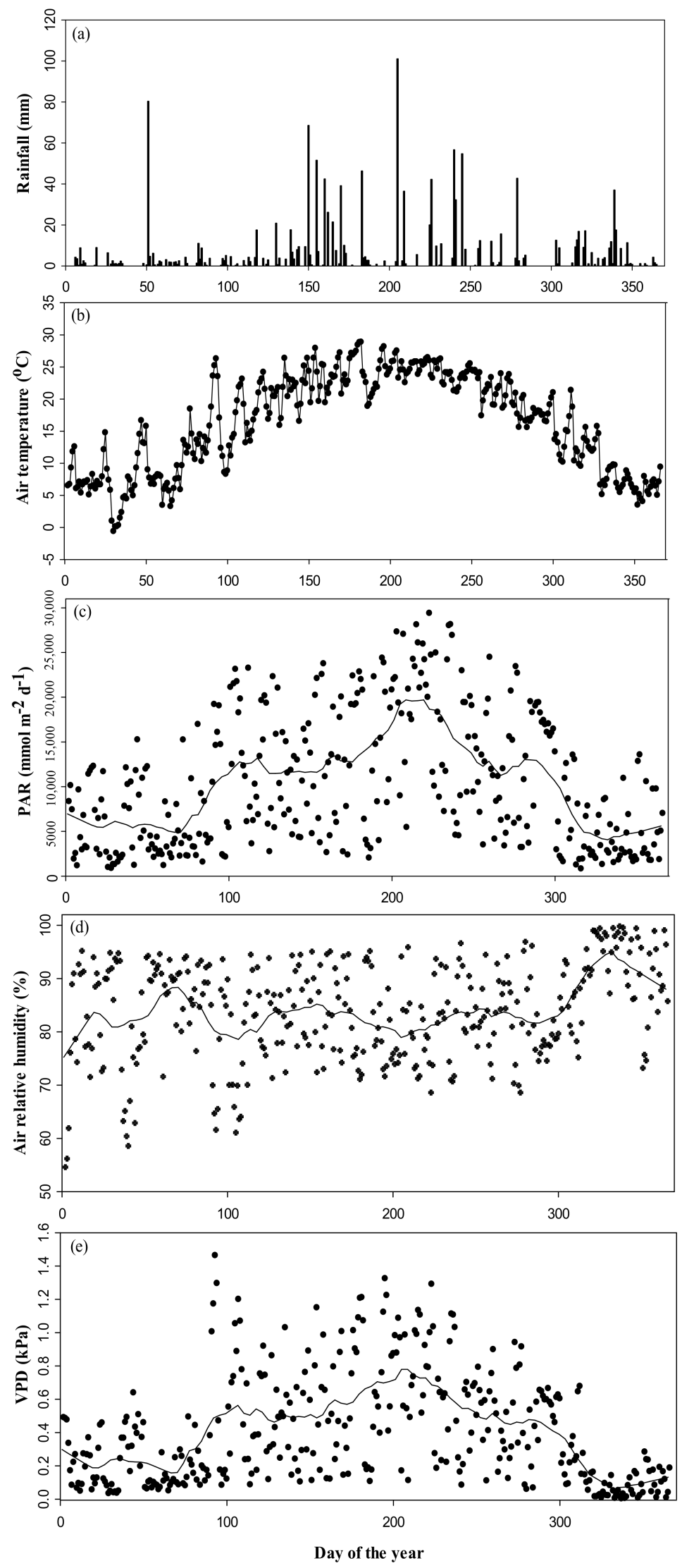

Figure 2. Variation of daily environmental variables of the study plot in 2015. (a) rainfall (mm); (b) air temperature $\left(\mathrm{T}_{\mathrm{a}}\right)\left({ }^{\circ} \mathrm{C}\right)$; (c) photosynthetically-active radiation (PAR) $\left(\mathrm{mmol} \mathrm{m}^{-2} \mathrm{day}^{-1}\right)$; $(\mathbf{d})$ air relative humidity $(\mathrm{RH})(\%)$; and (e) vapor pressure deficit (VPD) (kPa). 


\subsection{Sapwood Area and Its Relationship with DBH}

A regression equation relating $A_{\mathrm{S}}$ to $\mathrm{DBH}$ was derived from the cores of 40 sampled trees (Figure 3 ). The $A_{\mathrm{s}}$ of Chinese fir trees was well fitted by a power function of DBH $\left(A_{\mathrm{s}}=0.755 \times D B H^{1.8777}\right.$, $\left.R^{2}=0.984, p<0.001\right)$. Based on this equation, the $A_{\mathrm{s}}$ of Chinese fir trees in the study plot ranged from 19 to $281 \mathrm{~cm}^{2}$ with a mean value of $124 \mathrm{~cm}^{2}$ and the total $A_{\mathrm{s}}$ of the plot $\left(A_{\mathrm{ST}}\right)$ was $1 \mathrm{~m}^{2}$.

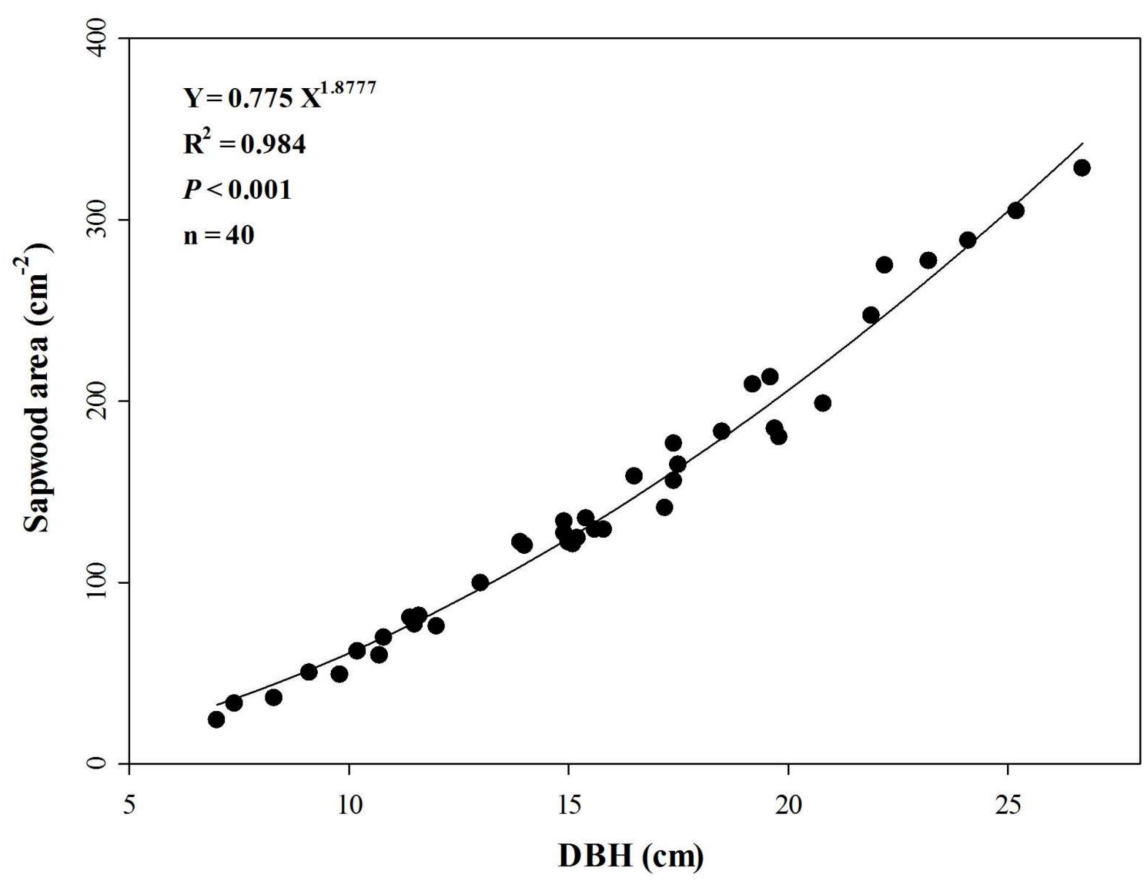

Figure 3. Relationship between sapwood area $\left(A_{\mathrm{S}}\right)$ and tree diameter at breast height $(\mathrm{DBH})$ for Chinese fir plantations.

\subsection{Accuracy and Error of the Calibrated Equation and Variations in SFD}

The relationship between $S F D$ values, estimated from the original Granier equation and measured via the gravimetric method, is shown in Figure 4a. The SFD values measured by the gravimetric method for different stem segments ranged from 0.019 to $0.208 \mathrm{~cm}^{3} \mathrm{~m}^{-2} \mathrm{~s}^{-1}$. Overall, the original Granier equation underestimated the actual $S F D$, and this error became more pronounced as $S F D$ increased. The average percentage error between the SFD measured by the gravimetric method and the SFD estimated via the original Granier equation was $54 \%$.

The values of parameters $a$ and $b$ after the calibration for Chinese firs differed from those in the original Granier equation (Equation (1)) (Figure 4b), in particular for $a$. The calibrated parameters of the new equation, based on the data for the laboratory experiment, were 0.0253 for $a$ and 1.2259 for $b$, implying that the values originally proposed had errors of $+112.6 \%$ and $-0.4 \%$ for Chinese firs. For all of the 18 trees sampled, the mean SFD in 2015 was $0.0012 \mathrm{~cm}^{3} \mathrm{~cm}^{-2} \mathrm{~s}^{-1}$, with values ranging from 0.000052 (tree no. 1) to $0.0020 \mathrm{~cm}^{3} \mathrm{~cm}^{-2} \mathrm{~s}^{-1}$ (tree no. 17). The coefficient of variation (CV) of the SFD for the 18 trees was $38.6 \%$. Figure 5 shows that SFD was significantly and positively correlated with $\operatorname{DBH}\left(R^{2}=0.90, p<0.001\right)$ and tree height $\left(R^{2}=0.71, p<0.001\right)$. 


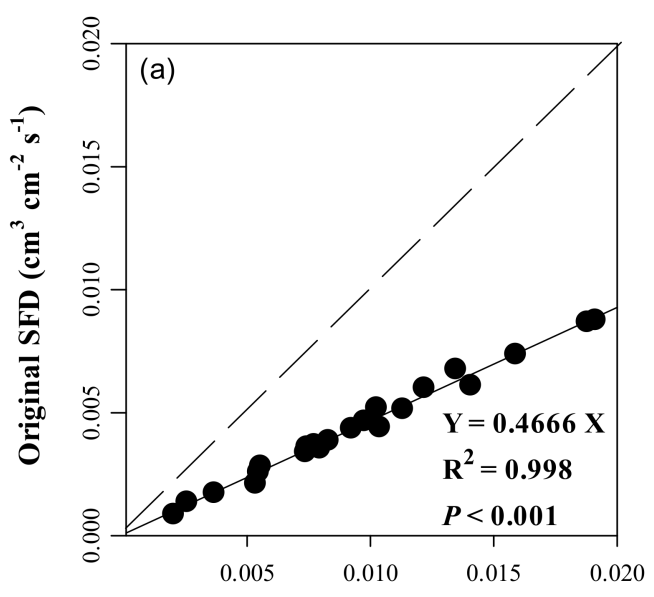

Measured SFD $\left(\mathrm{cm}^{3} \mathrm{~cm}^{-2} \mathrm{~s}^{-1}\right)$

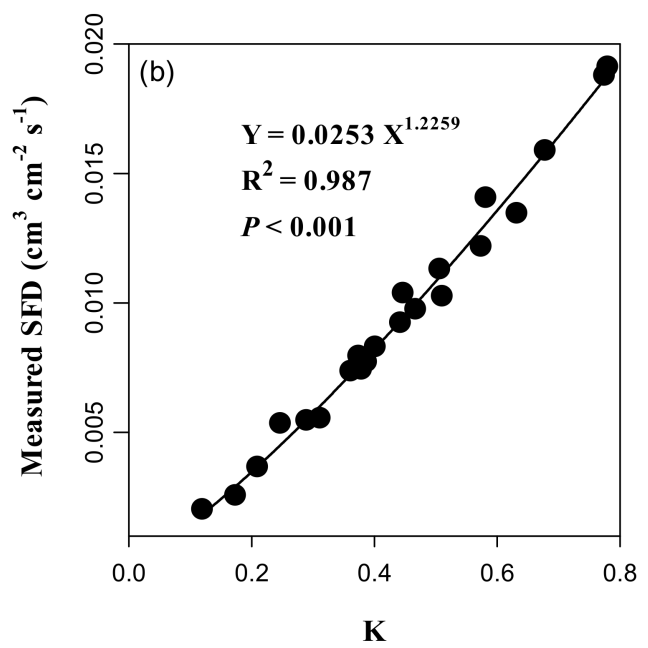

Figure 4. (a) A comparison of the SFD values estimated by the Granier equation of the original parameters ( $a=0.0119, b=1.231)$ and measured via the gravimetric method. The dashed line is the 1:1 line; (b) the relationship between the SFD values measured by the gravimetric method and the dimensionless sap flow index $K$ for Chinese firs.

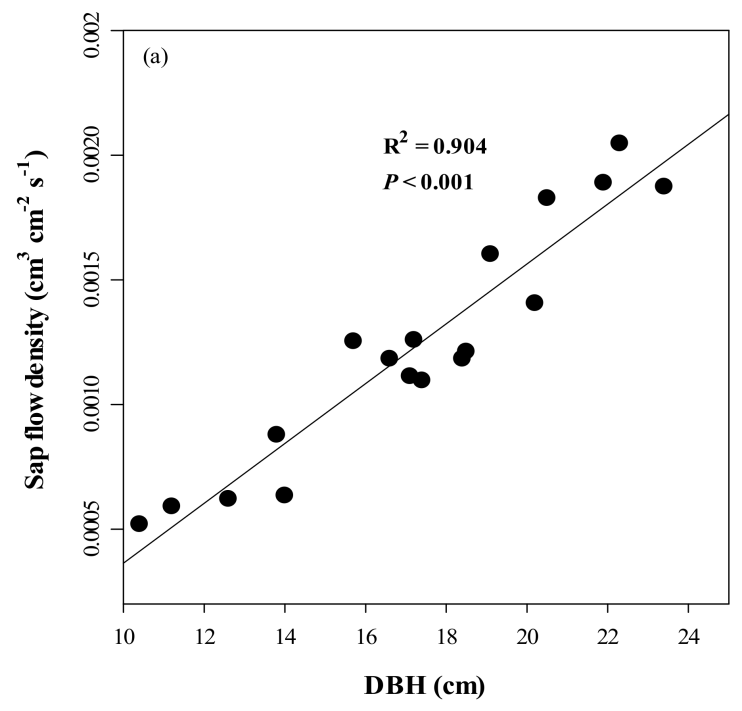

Figure 5. Cont. 


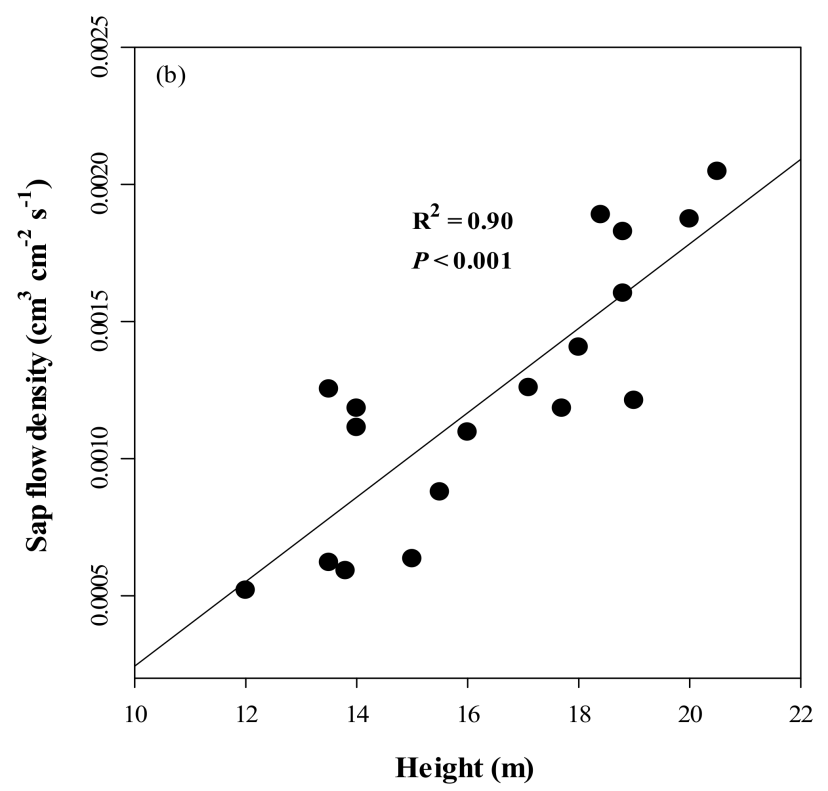

Figure 5. The relationship between sap flow density (SFD) and (a) tree diameter at breast height (DBH); and (b) tree height.

\subsection{Seasonal Dynamics of $E_{S}$ and Relationships between $E_{s}$ and Climate Factors}

The total $E_{\mathrm{s}}$ of Chinese firs was $522.1 \mathrm{~mm}$, about $37.3 \%$ of the total rainfall over the study period. Daily $E_{\mathrm{s}}$ reached an average of $1.4 \mathrm{~mm} \mathrm{day}^{-1}$, with values ranging from 0 to $5.0 \mathrm{~mm}$ (Figure 6). $E_{\mathrm{S}}$ increased gradually from January to May (early growing season), maintained high values in June, July, and August (middle growing season), with a maximum value of $5.0 \mathrm{~mm}$ day $^{-1}$ occurring on June 29 (day 180), and decreased gradually from September (late growing season) to December (Figure 6). The total $E_{\mathrm{s}}$ during the growing season from April to October was $468.9 \mathrm{~mm}$, about $89.8 \%$ of the total $E_{\mathrm{s}}$ of the whole year, with the lowest monthly cumulative $E_{\mathrm{s}}$ value at $47.6 \mathrm{~mm}$ in October, and with the highest monthly cumulative $E_{\mathrm{s}}$ value at $84.9 \mathrm{~mm}$ in July (Figure 7).

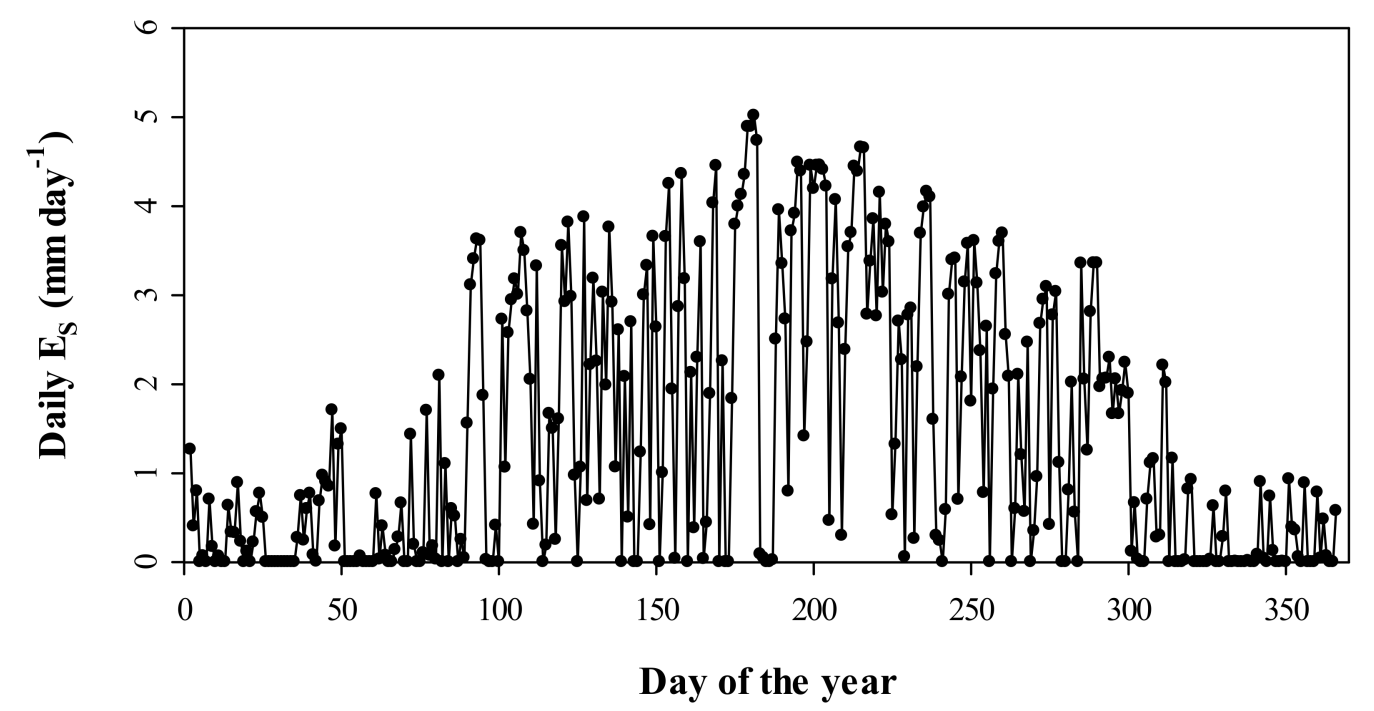

Figure 6. The variation of daily stand transpiration $\left(E_{\mathrm{s}}\right)$ in 2015. 


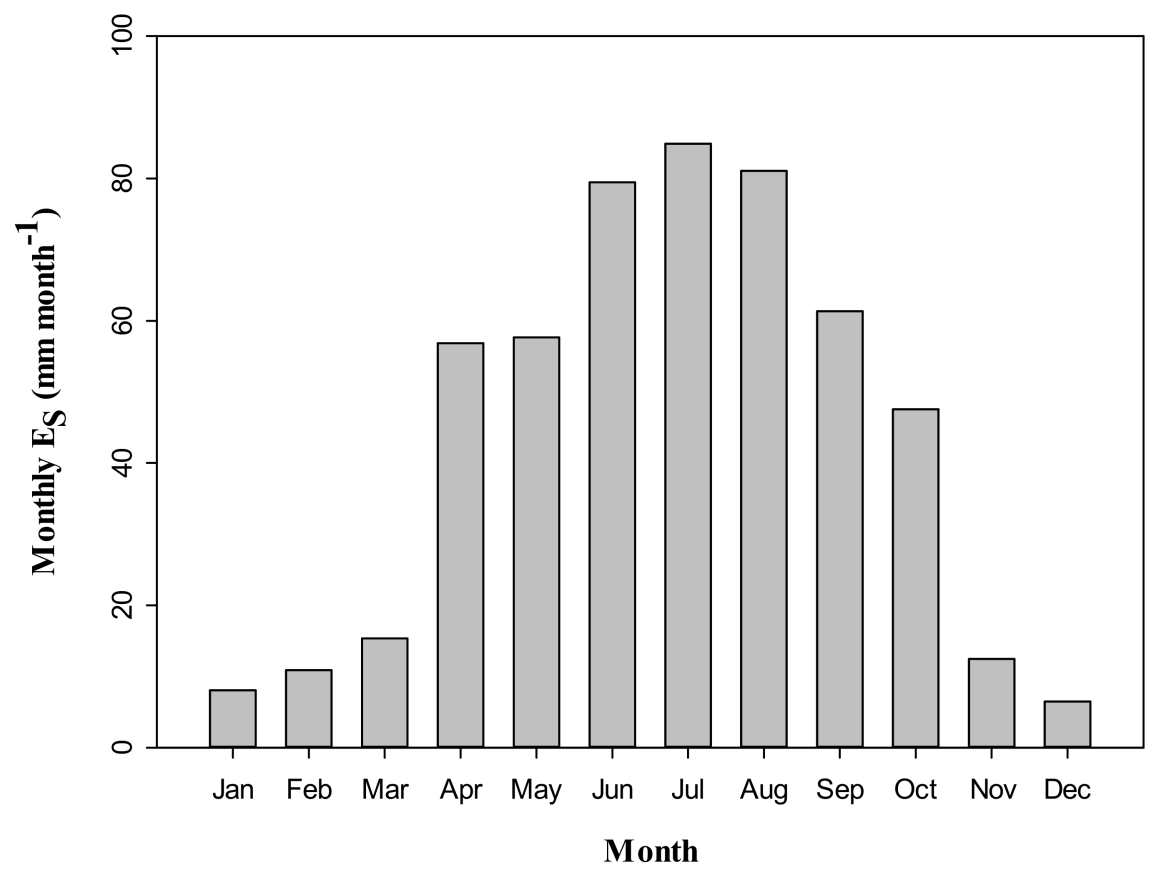

Figure 7. The cumulative monthly stand transpiration $\left(E_{\mathrm{s}}\right)$ during the study period.

To elucidate the different influences of the climatic factors on $E_{\mathrm{S}}$ over the daily and monthly timescales, the relationships between $E_{\mathrm{s}}$ and rainfall, $\mathrm{T}_{\mathrm{a}}, \mathrm{RH}, \mathrm{PAR}$, and VPD were respectively analyzed. On a daily timescale, linear regression showed that $E_{\mathrm{s}}$ was significantly and positively correlated with $\mathrm{T}_{\mathrm{a}}\left(R^{2}=0.56, p<0.001\right)$ and PET $\left(R^{2}=0.91, p<0.001\right)$, but negatively correlated with $\mathrm{RH}\left(R^{2}=0.48\right.$, $p<0.001)$. There was no obvious relationship between $E_{\mathrm{S}}$ and precipitation $(p>0.05)$. Including VPD and PAR as the independent variables, the exponential threshold models explained $87.2 \%$ and $80.7 \%$ variability of daily $E_{\mathrm{s}}$, respectively (Figure 8 ).

On a monthly timescale, $E_{\mathrm{S}}$ was significantly and positively correlated with monthly precipitation $\left(R^{2}=0.55, p<0.001\right), \operatorname{PAR}\left(R^{2}=0.93, p<0.001\right), \operatorname{VPD}\left(R^{2}=0.96, p<0.001\right), \mathrm{T}_{\mathrm{a}}\left(R^{2}=0.53, p<0.001\right)$, and PET $\left(R^{2}=0.98, p<0.001\right)$. However, no obvious relationship was found between monthly $E_{\mathrm{S}}$ and $\mathrm{RH}(p>0.05)$ (Figure 9).
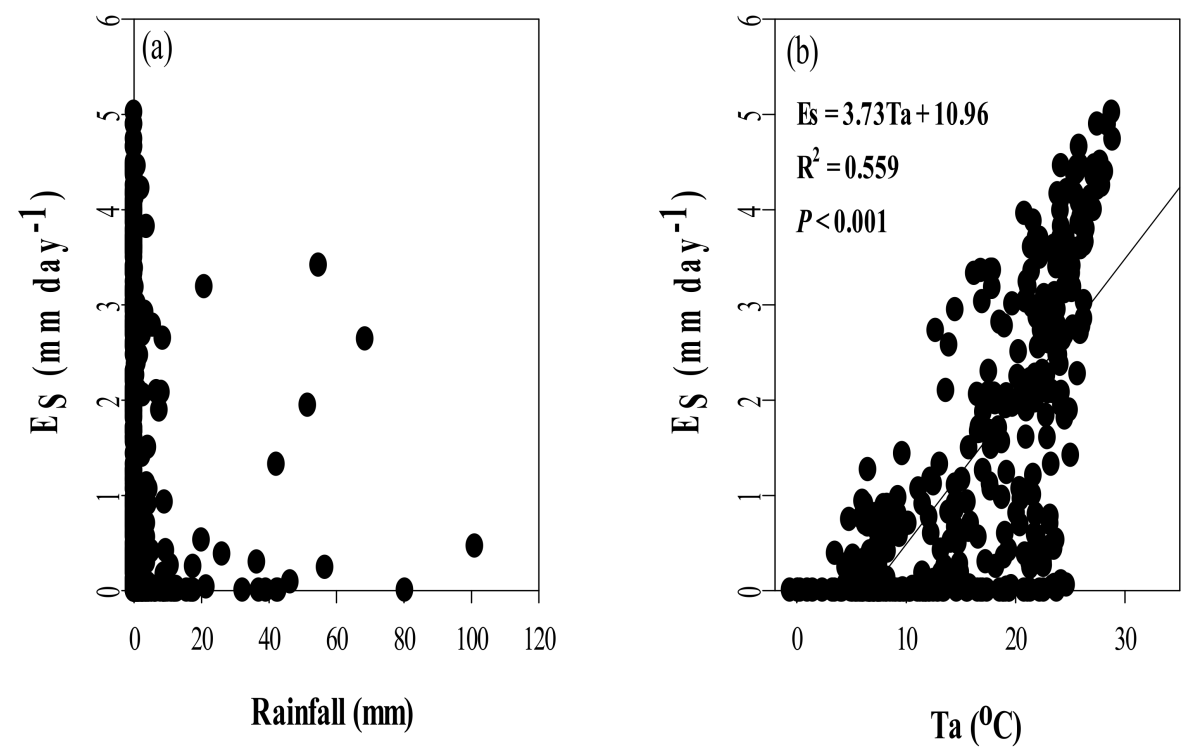

Figure 8. Cont. 

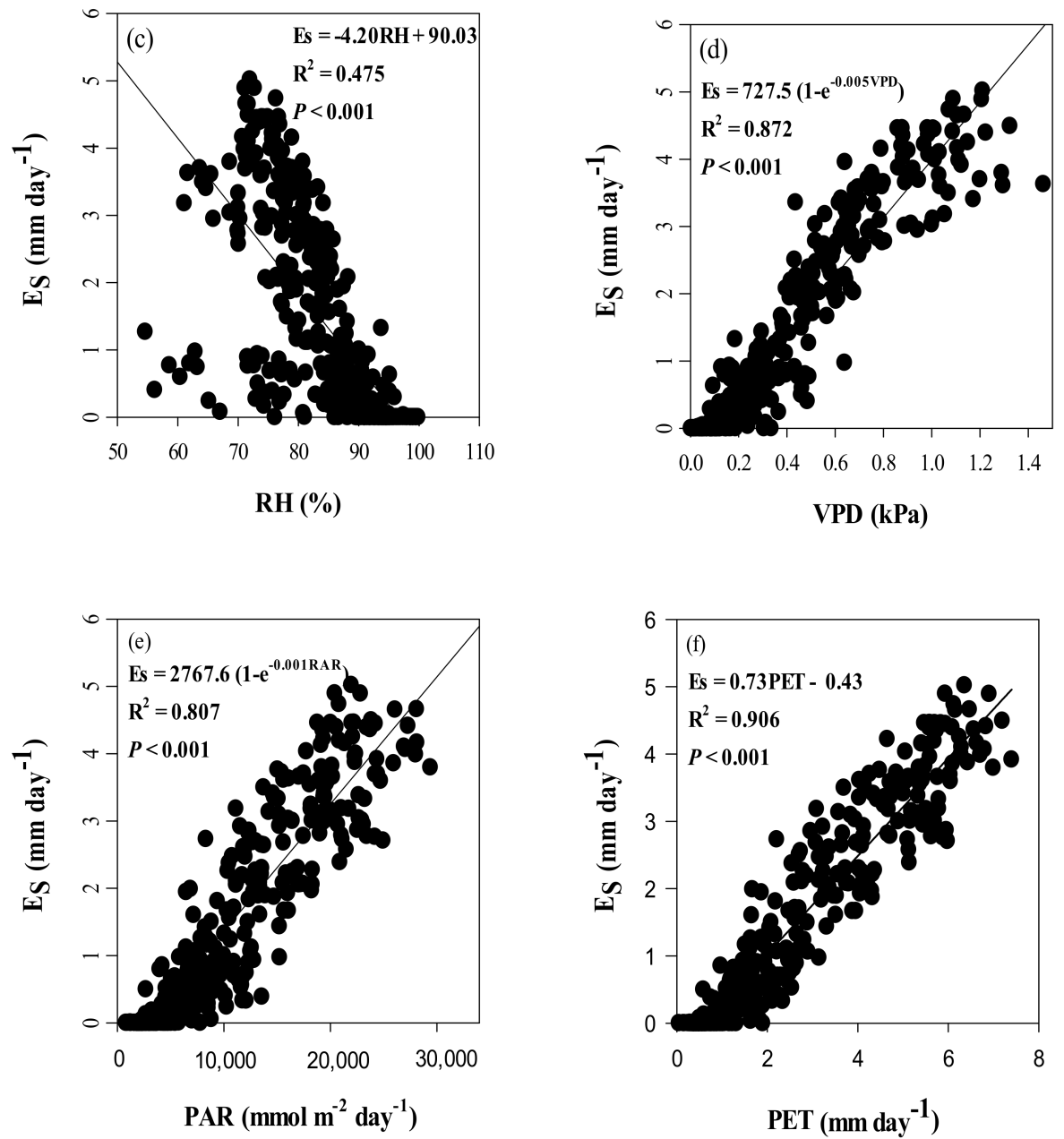

Figure 8. The relationships between the daily stand transpiration $\left(E_{\mathrm{S}}\right)(\mathrm{mm})$ and (a) rainfall $(\mathrm{mm})$; (b) air temperature (Ta) $\left({ }^{\circ} \mathrm{C}\right)$; (c) photosynthetically-active radiation (PAR) $\left(\mathrm{mmol} \mathrm{m}^{-2} \mathrm{day}^{-1}\right)$; (d) air relative humidity (RH) (\%); (e) vapor pressure deficit (VPD) (Kpa); and (f) potential evapotranspiration (PET) (mm) during the study period.
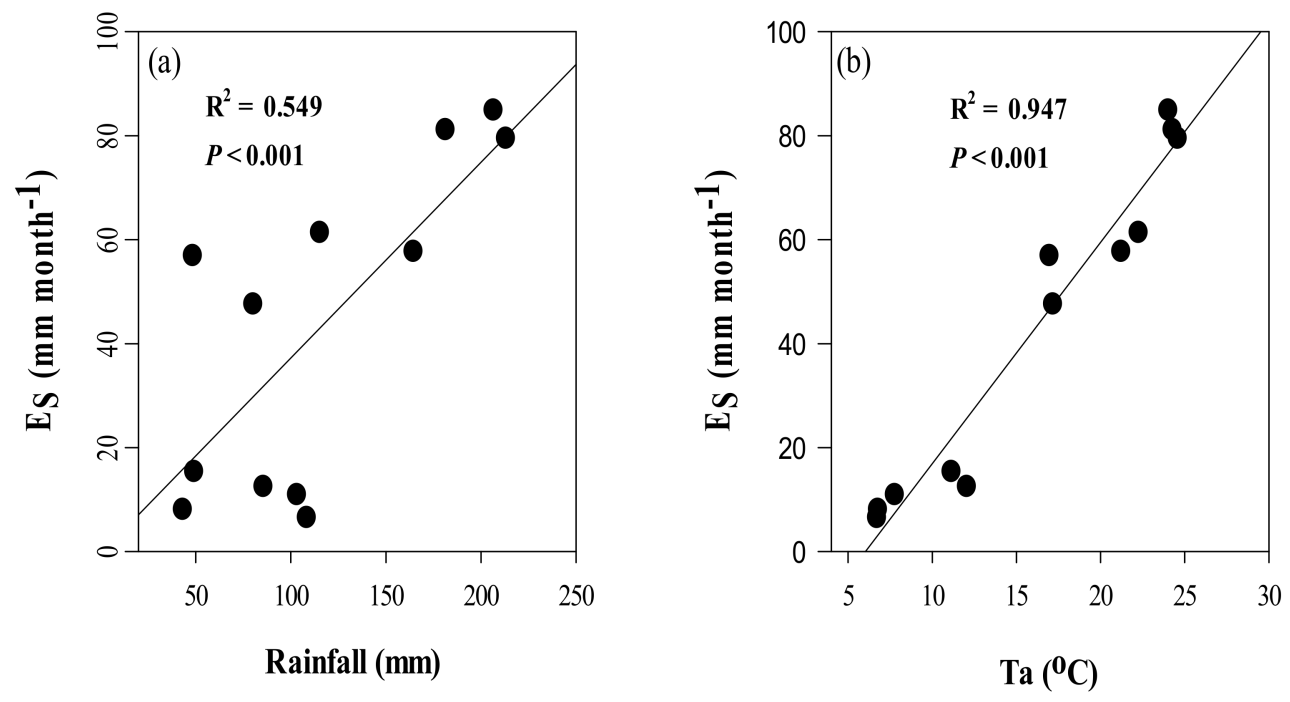

Figure 9. Cont. 

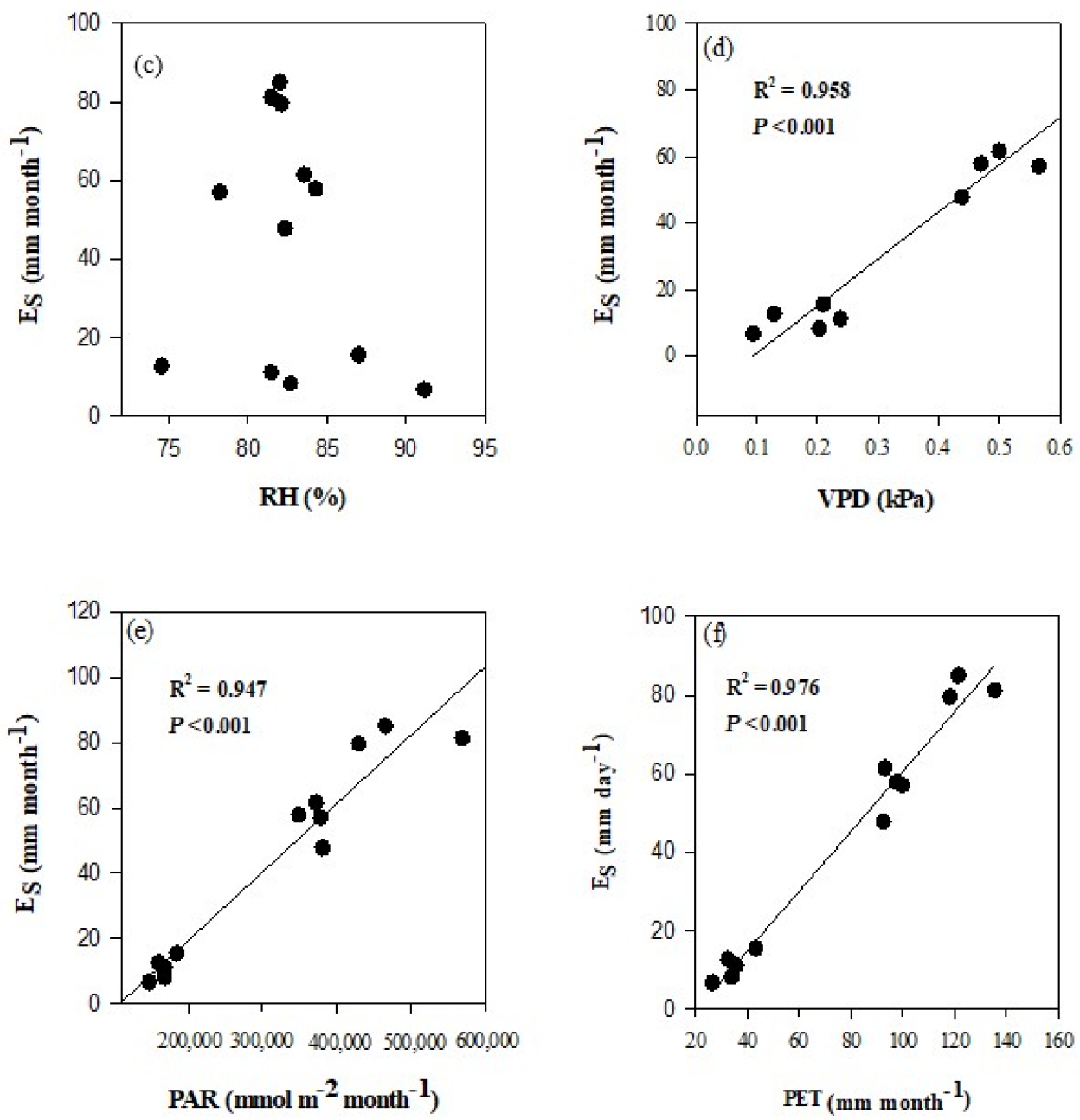

Figure 9. The relationships between monthly stand transpiration $\left(E_{\mathrm{S}}\right)(\mathrm{mm})$ and (a) rainfall $(\mathrm{mm})$; (b) air temperature $\left(\mathrm{T}_{\mathrm{a}}\right)\left({ }^{\circ} \mathrm{C}\right)$; (c) photosynthetically-active radiation (PAR) $\left(\mathrm{mmol} \mathrm{m}{ }^{-2} \mathrm{month}^{-1}\right)$; (d) air relative humidity (RH) (\%); and (e) vapor pressure deficit (VPD) (Kpa); and (f) potential evapotranspiration (PET) (mm) during the study period.

\section{Discussion}

\subsection{Calibration of Parameters for the Original Granier Equation}

The TDP method is one of the most commonly used techniques to measure sap flow. Nevertheless, if species-specific parameters were not taken into account, the method could generate large errors in the plant water use estimates $[10,13,33]$. Some studies have discussed whether the TDP method should be recalibrated for a specific species $[8,13]$. Using the gravimetric approach, our recalibrated experiments demonstrated that the estimates of the original TDP differed substantially from the actual $S F D$. The large errors in TDP were associated with the parameters $a$ and especially $b$ from the original empirical equation defined by Granier $[9,29]$. The calibrated parameters in this study were 0.0253 for $a$ and 1.2259 for $b\left(R^{2}=0.987\right)$, illustrating that the values originally proposed had an error of $+112.6 \%$ and $-0.4 \%$ for Chinese firs. This resulted in an overall $54 \%$ error in SFD (i.e., approximately 1.5 times the sap flux density calculated from Equation (1)). Using the same method, Lu and Chacko [38] found that the TDP method underestimated cumulative daily SFD by 6-10\% in two Mangifera indica trees. Steppe et al. [33] found an underestimate of $S F D$ by $60 \%$ in Fagus grandifolia trees. The different degrees of errors between estimated and actual SFD among species imply that the parameter values ( $a$ and $b$ ) in the original equation may not be appropriate for estimating the TDP of all species. Thus, there are 
no universal $a$ and $b$ parameter values that are suitable for all tree species when accurately estimating the SFD from the TDP method.

\section{2. $E_{s}$ Estimates for Chinese Fir Plantations}

Several studies have reported the existence of significant relationships between tree characteristics (i.e., tree height or DBH) and the water use of trees [34,39]. These relationships could be explained by energy limitations in our study plot. Shinohara et al. [34] reported a clear relationship between SFD and DBH in Japanese cedar forests. Similarly, SFD was found to be significantly and positively correlated with DBH and tree height in our study (Figure 5). These results indicate that C. lanceolata forests may not suffer from water availability constraints, and that their main constraint in transpiration in our study plot is light and atmospheric evaporative demand availability. Furthermore, SFD estimates were greatly affected by large trees with greater sapwood areas. In this study, a strong significant and positive correlation was found between SFD with $\mathrm{DBH}\left(R^{2}=0.91, p<0.01\right)$, and there was an approximately fourfold difference between the largest and the smallest SFD (Figure 5a).

The results of this study provide quantitative information on transpiration at the stand level. During the study period, the total $E_{\mathrm{s}}$ of $C$. lanceolata was $37.3 \%$ of the gross rainfall and daily $E_{\mathrm{S}}$ had an average value of 1.43. In other studies on coniferous forests, some transpiration observations were higher than the present study, but others were lower. For example, the $E_{\mathrm{s}}$ of a temperate Pinus tabulaeformis plantation varied from 1.4 and $2.2 \mathrm{~mm} \mathrm{day}^{-1}$, with a mean $E_{\mathrm{s}} 1.8 \mathrm{~mm} \mathrm{day}^{-1}$ in the Loess Plateau region of China [40]. However, some researchers have reported that canopy transpiration rates in old growth temperate conifer stands range from 0.4 to $1.5 \mathrm{~mm} \mathrm{day}^{-1}$, with a mean of $0.9 \mathrm{~mm} \mathrm{day}^{-1}[41,42]$. These differences are reasonable because $E_{\mathrm{s}}$ is significantly affected by the physiology of trees [43], stand density [44], stand age [45], and environmental conditions [40,46].

Strong seasonal changes of $E_{\mathrm{S}}$ were observed in this study (Figures 6 and 7 ), with Es being larger in the growing season than in the dormant season. This seasonal variation in $E_{\mathrm{S}}$ has generally been observed in temperate and tropical systems [21,41]. This has several explanations. First, in accordance with the humid conditions found at the study site, the drivers of $E_{\mathrm{S}}$ (mainly VPD and PAR) were always greater in the growing season than in the dormant season (Figure 2). Second, our study site has a typical humid subtropical monsoon climate, where summer is a wet season while winter is a dry season, resulting in a soil water deficit in autumn and winter, which could inevitably reduce $E_{\mathrm{s}}$. In this study, in spring, the PAR and VPD were relatively low and rainfall rarely occurred. Conversely, in autumn, the rainfall increased the soil water content without increasing the soil moisture, but PAR and VPD were still relatively high, so the rates of $E_{\mathrm{S}}$ that occurred during spring and autumn were between those found in the summer and winter.

\subsection{Effects of Climate Variables on $E_{s}$ in Chinese Fir Plantation}

Previous studies have found that a given forest stand $E_{\mathrm{S}}$ is mainly affected by several climate variables, such as VPD, Rs, and air temperature [22,47]. Plant stomatal responses to Rs and VPD are the two key factors in terms of the trade-off between maximizing photosynthesis and minimizing transpiration [19,47,48]. Threshold responses were observed in $E_{\mathrm{S}}$ to VPD and Rs [35,47,49]. Ewers et al. [36] developed an exponential saturation to describe the threshold relationship between $E_{\mathrm{S}}$ and environmental factors, which was widely used to examine the regulation of environmental factors on $E_{\mathrm{S}}[47,50]$. For example, the model with VPD and Rs can explain $8 \%$ and $57 \%$ variations in daily $E_{\mathrm{S}}$ in Japanese cedar forests, respectively [51]. Ghimire et al. [47] showed that $E_{\mathrm{s}}$ exhibited a threshold relationship with VPD and Rs in a planted coniferous forest in the Lesser Himalaya of Central Nepal, with threshold values of $0.4 \mathrm{kPa}$ for VPD and $200 \mathrm{~W} \mathrm{~m}^{-2}$ for Rs. Jiao et al. [19] reported that $E_{\mathrm{S}}$ exhibited a threshold relationship with VPD and Rs in a black locust (Robinia pseudoacacia) plantation on the semi-arid Loess Plateau, China, with threshold values of $1.5 \mathrm{kPa}$ for VPD and $250 \mathrm{~W} \mathrm{~m}^{-2}$ for Rs.

In this study, daily $E_{\mathrm{S}}$ increased sharply with increasing VPD and the VPD threshold was approximately $1.2 \mathrm{kPa}$. Similarly, $E_{\mathrm{s}}$ reasonably increased with increasing RAR and leveled off 
at a threshold value of around 23,000 $\mathrm{mmol} \mathrm{m}^{-2}$ day $^{-1}$. Ewers' model including VPD or PAR can explain the variability of daily $E_{\mathrm{s}}$. RAR could explain $87.2 \%$ and $80.7 \%$ variations in daily $E_{\mathrm{s}}$ in Chinese fir forest (Figure 8). Moreover, most previous studies have focused on the relationship between $E_{\mathrm{s}}$ and other environmental factors such as PAR, VPD, and $T_{a}$ alone [19,47], and few on the relationship between $E_{\mathrm{S}}$ and PET [50]. Our study showed that PET, the lumped variable that is usually used to reflect atmospheric water demand, was more highly correlated with $E_{\mathrm{s}}$ than a single environment factor at both the daily scale (Figure 8 ) and the monthly scale (Figure 9). This finding indicates the integrative impact of environmental factors on $E_{\mathrm{s}}$.

At the monthly timescale, the highest monthly $E_{\mathrm{s}}$ occurred with the highest amount of precipitation in July 2010. The values were relatively high during the wet months when the region experienced higher precipitation (June, July, and August). VPD and PAR explained 96\% and 95\% variations in monthly $E_{\mathrm{s}}$, respectively. $\mathrm{T}_{\mathrm{a}}$ also explained $95 \%$ of the variations in monthly $E_{\mathrm{s}}$ (Figure 9 ). PAR and VPD usually control the transpiration rate by affecting plant stomatal conductance at a daily timescale [8]. At a monthly or seasonal timescale, variations in $E_{\mathrm{s}}$ are controlled by plant phenology and environmental factors (e.g., climatic conditions and availability of soil water) [47,52]. Granier et al. [22] found that both Rs and VPD controlled the transpiration rate by affecting stomatal conductance, with VPD being the most correlated at a daily scale. At monthly scale, however, Wang et al. [4] found that rainfall might contribute towards influencing $E_{\mathrm{s}}$. This could explain the different influences between daily and monthly timescales. Jiao et al. [19] found that the status of soil water content at the beginning of the growing season had large impacts on $E_{\mathrm{s}}$ in a black locust plantation on the semi-arid Loess Plateau, China. Hence, a future study should take soil water condition into consideration in order to understand variations in $E_{\mathrm{s}}$ at different timescales.

\section{Conclusions}

In this study, a species-specific parameter calibration was performed for the original Granier equation for Chinese fir trees in southern China. The calibrated parameters resulted in considerably different estimates of $S F D$ for Chinese firs when compared with the original calibration equation, which underestimated $S F D$ by up to $54 \%$. These results suggest that there is no universal set of parameter $(a$ and $b$ ) values that are suitable for accurately calculating SFD measurements from TDP measurements; a relatively simple calibration appreciably improved the accuracy of the TDP. When accurate estimates of the water budget must be carried out in tree-dominated ecosystems, tree-to-tree variations in SFD should be considered. Our study also indicated that the dominant climatic factors have different effects on $E_{\mathrm{S}}$ at different temporal scales.

Acknowledgments: This study was supported by the Key Program of the National Natural Science Foundation of China (31290221); the National Natural Science Foundation of China (31700636), the Project funded by China Postdoctoral Science Foundation (2017M612605), and Huitong Forest Ecological Station Program funded by the State Forestry Administration of China. We thank the post-graduate Renhui Li for collecting data in the field work.

Author Contributions: Zhonghui Zhao and Wenhua Xiang conceived and designed the experiments; Shuai Ouyang, Kaiyu Xiao, and Chuanhong Xu performed the experiments; Pifeng Lei, Jiangrong Li and Shuai Ouyang analyzed the data; Xiangwen Deng contributed technical advice and Shuai Ouyang wrote the paper.

Conflicts of Interest: The authors declare no conflict of interest.

\section{References}

1. Bosch, D.D.; Marshall, L.K.; Teskey, R. Forest transpiration from sap flux density measurements in a Southeastern Coastal Plain riparian buffer system. Agric. For. Meteorol. 2014, 187, 72-82. [CrossRef]

2. Yan, M.J.; Zhang, J.G.; He, Q.Y.; Shi, W.Y.; Otsuki, K.; Yamanaka, N.; Du, S. Sapflow-Based Stand Transpiration in a Semiarid Natural Oak Forest on China's Loess Plateau. Forests 2016, 7, 227. [CrossRef]

3. Burba, G.G.; Verma, S.B. Seasonal and interannual variability in evapotranspiration of native tallgrass prairie and cultivated wheat ecosystems. Agric. For. Meteorol. 2005, 135, 190-201. [CrossRef] 
4. Wang, Y.L.; Liu, G.B.; Kume, T.; Otsuki, K.; Yamanaka, N.; Du, S. Estimating water use of a black locust plantation by the thermal dissipation probe method in the semiarid region of Loess Plateau, China. J. For. Res. 2010, 15, 241-251. [CrossRef]

5. Van de Wal, B.A.E.; Guyot, A.; Lovelock, C.; EvLockington, D.A.; Steppe, K. Influence of temporospatial variation in sap flux density on estimates of whole-tree water use in Avicennia marina. Trees 2015, 29, $215-222$. [CrossRef]

6. Wei, X.; Sun, G. Watershed Ecosytem Process and Management; Higher Education Press: Beijing, China, 2009.

7. Kool, D.; Agam, N.; Lazarovitch, N.; Heitman, J.L.; Sauer, T.J.; Ben-Gal, A. A review of approaches for evapotranspiration partitioning. Agric. For. Meteorol. 2014, 184, 56-70. [CrossRef]

8. Lu, P.; Urban, L.; Ping, Z. Granier's thermal dissipation probe (TDP) method for measuring sap flow in trees: Theory and practice. Acta Bot. Sin. 2004, 46, 631-646.

9. Granier, A. Une nouvelle méthode pour la mesure du flux de sève brute dans le tronc des arbres. Ann. For. Sci. 1985, 42, 193-200. [CrossRef]

10. Smith, D.M.; Allen, S.J. Measurement of sap flow in plant stems. J. Exp. Bot. 1996, 47, 1833-1844. [CrossRef]

11. Sun, H.; Aubrey, D.P.; Teskey, R.O. A simple calibration improved the accuracy of the thermal dissipation technique for sap flow measurements in juvenile trees of six species. Trees 2012, 26, 631-640. [CrossRef]

12. Paudel, I.; Kanety, T.; Cohen, S. Inactive xylem can explain differences in calibration factors for thermal dissipation probe sap flow measurements. Tree Physiol. 2013, 33, 986-1001. [CrossRef] [PubMed]

13. Bush, S.E.; Hultine, K.R.; Sperry, J.S.; Ehleringer, J.R. Calibration of thermal dissipation sap flow probes for ring-and diffuse-porous trees. Tree Physiol. 2010, 30, 1545-1554. [CrossRef] [PubMed]

14. Dragoni, D.; Lakso, A.N.; Piccioni, R.M. Transpiration of apple trees in a humid climate using heat pulse sap flow gauges calibrated with whole-canopy gas exchange chambers. Agric. For. Meteorol. 2005, 130, 85-94. [CrossRef]

15. Gebauer, T.; Horna, V.; Leuschner, C. Variability in radial sap flux density patterns and sapwood area among seven co-occurring temperate broad-leaved tree species. Tree Physiol. 2008, 28, 1821-1830. [CrossRef] [PubMed]

16. Du, S.; Wang, Y.L.; Kume, T.; Zhang, J.G.; Otsuki, K.; Yamanaka, N.; Liu, G.B. Sapflow characteristics and climatic responses in three forest species in the semiarid Loess Plateau region of China. Agric. For. Meteorol. 2011, 151, 1-10. [CrossRef]

17. Denmead, O.T.; Shaw, R.H. Availability of soil water to plants as affected by soil moisture content and meteorological conditions. Agron. J. 1962, 54, 385-390. [CrossRef]

18. Keenan, T.; Sierra, J.M.; Lloret, F.; Ninyerola, M.; Sabate, S. Predicting the future of forests in the Mediterranean under climate change, with niche- and process based models: $\mathrm{CO}_{2}$ matters! Glob. Chang. Biol. 2011, 17, 565-579. [CrossRef]

19. Jiao, L.; Lu, N.; Sun, G.; Ward, E.J.; Fu, B. Biophysical controls on canopy transpiration in a black locust (Robinia pseudoacacia) plantation on the semi-arid Loess Plateau, China. Ecohydrology 2016, 9, 1068-1081. [CrossRef]

20. Phillips, N.; Oren, R. Intra- and inter-annual variation in transpiration of a pine forest. Ecol. Appl. 2001, 11, 385-396. [CrossRef]

21. Zeppel, M.J.; Yunusa, I.A.; Eamus, D. Daily, seasonal and annual patterns of transpiration from a stand of remnant vegetation dominated by a coniferous Callitris species and a broad-leaved Eucalyptus species. Physiol. Plant. 2006, 27, 413-422. [CrossRef]

22. Granier, A.; Biron, P.; Köstner, B.; Gay, L.; Najjar, G. Comparisons of xylem sap flow and water vapour flux at the stand level and derivation of canopy conductance for Scots pine. Theor. Appl. Climatol. 1996, 53, 115-122. [CrossRef]

23. Tian, D. The Functioning of Chinese Fir Plantation Ecosystem; Science Press: Beijing, China, 2005.

24. Lu, Y.; Coops, N.C.; Wang, T.; Wang, G. A process-based approach to estimate Chinese fir (Cunninghamia lanceolata) distribution and productivity in southern China under climate change. Forests 2015, 6, 360-379. [CrossRef]

25. Lei, J. Forest Resources in China; Chinese Forestry Publishing House: Beijing, China, 2005.

26. Wang, B.; Li, S.N.; Guo, H. The assessment of forest ecosystem services evaluation in Jiangxi Province. Jiangxi Sci. 2007, 5, 554-587. 
27. Zhong, Z.H.; Kang, W.X.; Tian, D.L.; Xiang, W.H.; Yan, W.D. Sap flow rate and its relationship with environmental factors of Chinese fir plantation in Huitong, Hunan Province. Sci. Silvae Sin. 2009, 45, 127-132.

28. Yan, W.; Deng, X.; Chen, X.; Tian, D.; Xiang, W.; Peng, Y. Long-term variations of rainfall interception in different growth stages of Chinese fir plantations. Hydrol. Sci. J. 2015, 60, 2178-2188. [CrossRef]

29. Granier, A. Evaluation of transpiration in a Douglas-fir stand by means of sap flow measurements. Tree Physiol. 1987, 3, 309-320. [CrossRef] [PubMed]

30. Norman, J.M.; Campbell, G.S. An Introduction to Environmental Biophysics; Springer: New York, NY, USA, 1998.

31. Allen, R.G.; Pereira, L.S.; Raes, D.; Smith, M. Crop Evapotranspiration: Guidelines for Computing Crop Water Requirements; FAO Irrigation and Drainage Paper No. 56; The Food and Agriculture Organization (FAO): Rome, Italy, 1998.

32. Vertessy, R.; Benyon, R.; O'Sullivan, S.; Gribben, P. Relationships between stem diameter, sapwood area, leaf area and transpiration in a young mountain ash forest. Tree Physiol. 1995, 15, 559-567. [CrossRef] [PubMed]

33. Steppe, K.; De Pauw, D.J.W.; Doody, T.M.; Teskey, R.O. A comparison of sap flux density using thermal dissipation, heat pulse velocity and heat field deformation methods. Agric. For. Meteorol. 2010, 150, 1046-1056. [CrossRef]

34. Shinohara, Y.; Tsuruta, K.; Ogura, A.; Noto, F.; Komatsu, H.; Otsuki, K.; Maruyama, T. Azimuthal and radial variations in sap flux density and effects on stand-scale transpiration estimates in a Japanese cedar forest. Tree Physiol. 2013, 33, 550-558. [CrossRef] [PubMed]

35. Kumagai, T.; Aoki, S.; Shimizu, T.; Otsuki, K. Sap flow estimates of stand transpiration at two slope positions in a Japanese cedar forest watershed. Tree Physiol. 2007, 27, 161-168. [CrossRef] [PubMed]

36. Ewers, B.E.; Mackay, D.S.; Gower, S.T.; Ahl, D.E.; Burrows, S.N. Tree species effects on stand transpiration in northern Wisconsin. Water Resour. Res. 2002, 38, 1103. [CrossRef]

37. R Development Core Team. R: A Language and Environment for Statistical Computing; R Foundation for Statistical Computing: Vienna, Austria, 2015.

38. Lu, P.; Chacko, E. Evaluation of Granier's sap flux sensor in young mango trees. Agronomie 1998, 18, 461-471. [CrossRef]

39. Delzon, S.; Sartore, M.; Granier, A.; Loustau, D. Radial profiles of sap flow with increasing tree size in maritime pine. Tree Physiol. 2004, 24, 1285-1293. [CrossRef] [PubMed]

40. Fang, S.; Zhao, C.; Jian, S. Canopy transpiration of Pinus tabulaeformis plantation forest in the Loess Plateau region of China. Environ. Earth Sci. 2016, 75, 1-9. [CrossRef]

41. Zimmermann, R.; Schulze, E.D.; Wirth, C.; Schulze, E.E.; McDonald, K.C.; Vygodskaya, N.N.; Ziegler, W. Canopy transpiration in a chrono sequence of Central Siberian pine forests. Glob. Chang. Biol. 2000, 6, $25-37$. [CrossRef]

42. Moore, G.W.; Bond, B.J.; Jones, J.A.; Phillips, N.; Meinzer, F.C. Structural and compositional controls on transpiration in 40 and 450-year-old riparian forests in western Oregon, USA. Tree Physiol. 2004, 24, 481-491. [CrossRef] [PubMed]

43. Ocheltree, T.W.; Nippert, J.B.; Prasad, P.V.V. Stomatal responses to changes in vapor pressure deficit reflect tissue-specific differences in hydraulic conductance. Plant Cell Environ. 2014, 37, 132-139. [CrossRef] [PubMed]

44. Alsheimer, M.; Köstner, B.; Falge, E.; Tenhunen, J.D. Temporal and spatial variation in transpiration of Norway spruce stands within a forested catchment of the Fichtelgebirge, Germany. Ann. Sci. For. 1998, 55, 103-124. [CrossRef]

45. Ewers, B.E.; Gower, S.T.; Bond-Lamberty, B.; Wang, C.K. Effects of stand age and tree species on canopy transpiration and average stomatal conductance of boreal forests. Plant Cell Environ. 2005, 28, 660-678. [CrossRef]

46. Ma, L.; Lu, P.; Zhao, P.; Rao, X.Q.; Cai, X.A.; Zeng, X.P. Diurnal, daily, seasonal and annual patterns of sap-flux-scaled transpiration from an Acacia mangium plantation in South China. Ann. Sci. For. 2008, 65, 402. [CrossRef]

47. Ghimire, C.P.; Lubczynski, M.W.; Bruijnzeel, L.A.; Chavarro-Rincón, D. Transpiration and canopy conductance of two contrasting forest types in the Lesser Himalaya of Central Nepal. Agric. For. Meteorol. 2014, 197, 76-90. [CrossRef] 
48. Granier, A.; Huc, R.; Barigah, S.T. Transpiration of natural rain forest and its dependence on climatic factors. Agric. For. Meteorol. 1996, 78, 19-29. [CrossRef]

49. Chang, X.X.; Zhao, W.Z.; Liu, H.; Wei, X.; Liu, B.; He, Z.B. Qinghai spruce (Picea crassifolia) forest transpiration and canopy conductance in the upper Heihe River Basin of arid northwestern China. Agric. For. Meteorol. 2014, 198, 209-220. [CrossRef]

50. Zhang, J.G.; Guan, J.H.; Shi, W.Y.; Yamanaka, N.; Du, S. Interannual variation in stand transpiration estimated by sap flow measurement in a semi-arid black locust plantation, Loess Plateau, China. Ecohydrology 2015, 8, 137-147. [CrossRef]

51. Kumagai, T.; Tateishi, M.; Shimizu, T.; Otsuki, K. Transpiration and canopy conductance at two slope positions in a Japanese cedar forest watershed. Agric. For. Meteorol. 2008, 148, 1444-1455. [CrossRef]

52. Yan, C.; Wang, B.; Zhang, Y.; Zhang, X.; Takeuchi, S.; Qiu, G.Y. Responses of sap flow of deciduous and conifer trees to soil drying in a subalpine forest. Forests 2018, 9, 32. [CrossRef]

C 2018 by the authors. Licensee MDPI, Basel, Switzerland. This article is an open access article distributed under the terms and conditions of the Creative Commons Attribution (CC BY) license (http:/ / creativecommons.org/licenses/by/4.0/). 